\title{
Impacts of the East Asian summer monsoon on interannual variations of summertime surface-layer ozone concentrations over China
}

\author{
Y. Yang ${ }^{1,2}$, H. Liao ${ }^{1}$, and J. $\mathbf{L i}^{3,4}$ \\ ${ }^{1}$ State Key Laboratory of Atmospheric Boundary Layer Physics and Atmospheric Chemistry, Institute of Atmospheric \\ Physics, Chinese Academy of Sciences, Beijing, China \\ ${ }^{2}$ Graduate University of Chinese Academy of Science, Beijing, China \\ ${ }^{3}$ College of Global Change and Earth System Science, Beijing Normal University, Beijing, China \\ ${ }^{4}$ State Key Laboratory of Numerical Modeling for Atmospheric Sciences and Geophysical Fluid Dynamics, Institute of \\ Atmospheric Physics, Chinese Academy of Sciences, Beijing, China \\ Correspondence to: H. Liao (hongliao@mail.iap.ac.cn)
}

Received: 25 November 2013 - Published in Atmos. Chem. Phys. Discuss.: 4 February 2014

Revised: 1 May 2014 - Accepted: 27 May 2014 - Published: 4 July 2014

\begin{abstract}
We apply a global three-dimensional Goddard Earth Observing System (GEOS) chemical transport model (GEOS-Chem) driven by the NASA/GEOS-4 assimilated meteorological fields to quantify the impacts of the East Asian summer monsoon (EASM) on interannual variations of June-July-August (JJA) surface-layer $\mathrm{O}_{3}$ concentrations over China. With anthropogenic emissions fixed at year 2005 levels, the model simulation for years 1986-2006 shows that the changes in meteorological parameters alone lead to interannual variations in JJA surface-layer $\mathrm{O}_{3}$ concentrations by $2-5 \%$ over central eastern China, $1-3 \%$ in northwestern China, and $5-10 \%$ over the Tibetan Plateau as well as the border and coastal areas of southern China, as the interannual variations are relative to the average $\mathrm{O}_{3}$ concentrations over the 21 yr period. Over the years 1986-2006, the $\mathrm{O}_{3}$ concentration averaged over all of China is found to correlate positively with the EASM index with a large correlation coefficient of +0.75 , indicating that $\mathrm{JJA} \mathrm{O}_{3}$ concentrations are lower (or higher) in weaker (or stronger) EASM years. Relative to JJA surface-layer $\mathrm{O}_{3}$ concentrations in the strongest EASM years $\left(1990,1994,1997,2002\right.$, and 2006), O ${ }_{3}$ levels in the weakest EASM years $(1988,1989,1996,1998$, and 2003) are lower over almost all of China with a national mean lower $\mathrm{O}_{3}$ concentration by $2.0 \mathrm{ppbv}$ (parts per billion by volume; or $4 \%$ ). Regionally, the largest percentage differences in $\mathrm{O}_{3}$ concentration between the weakest and strongest EASM years are found to exceed $6 \%$ in northeastern China,
\end{abstract}

southwestern China, and over the Tibetan Plateau. Sensitivity studies show that the difference in transboundary transport of $\mathrm{O}_{3}$ is the most dominant factor that leads to lower- $\mathrm{O}_{3}$ concentrations in the weakest EASM years than in the strongest EASM years, which, together with the enhanced vertical convections in the weakest EASM years, explain about $80 \%$ of the differences in surface-layer $\mathrm{O}_{3}$ concentrations between the weakest and strongest EASM years. We also find that the impacts the EASM strength on JJA surface-layer $\mathrm{O}_{3}$ can be particularly strong (comparable in magnitude to the impacts on $\mathrm{O}_{3}$ by changes in anthropogenic emissions over years 1986-2006) for certain years. The largest increases in $\mathrm{O}_{3}$ by anthropogenic emissions are simulated over southeastern China, whereas the largest impacts of the EASM on $\mathrm{O}_{3}$ are found over central and western China.

\section{Introduction}

Tropospheric $\mathrm{O}_{3}$ is an air pollutant harmful to human health and ecosystems (Shindell et al., 2012). It is also (after $\mathrm{CO}_{2}$ and $\mathrm{CH}_{4}$ ) the third most important anthropogenic greenhouse gas (Intergovernmental Panel on Climate Change, IPCC, 2007). High $\mathrm{O}_{3}$ concentrations have been observed in many Chinese sites, with seasonal mean concentrations of 20-60 ppbv (parts per billion by volume; Tang et al., 1995; Yan et al., 1997, 2003; Cheung and Wang, 2001; Zhu et al., 
2004; Gao et al., 2005; Shao et al., 2006; H. Wang et al., 2005; Chou et al., 2006; Ding and Wang, 2006; T. Wang et al., 2006a, 2009; Takami et al., 2006; Tu et al., 2007; Ding et al., 2008; Lin et al., 2008; Xu et al., 2008; Yang et al., 2008; Zhang et al., 2008; Y. Wang et al., 2011) and episodic concentrations of exceeding $100 \mathrm{ppbv}$ (T. Wang et al., 2006b; Z. Wang et al., 2006; Duan et al., 2008). Concentrations of $\mathrm{O}_{3}$ are driven by a combination of precursor emissions and the regional meteorological conditions.

Meteorological parameters during summer in eastern China vary with the East Asian summer monsoon (EASM). The EASM prevails in May-September every year, with strong southerlies bringing clean, warm, and moist air from the oceans to eastern China and rain belts that stretch for thousands of kilometers in the west-east direction in eastern China (Tao and Chen, 1987; Wang and Ding, 2008). Previous observational and modeling studies have shown that such patterns of winds and precipitation of the EASM influence the seasonal variations of $\mathrm{O}_{3}$ in China (Chan et al., 1998; $\mathrm{Li}$ et al., 2007; He et al., 2008; Wang et al., 2011) and in the western Pacific region (Pochanart et al., 2002; Tanimoto et al., 2005; Yamaji et al., 2006). He et al. (2008) analyzed the seasonal variations of $\mathrm{O}_{3}$ concentrations measured over the period 2004-2006 and found that $\mathrm{O}_{3}$ concentrations peak in spring and autumn with a summer trough in central eastern China and the western Pacific, the areas that are influenced by clean air from the southern oceans during the summer monsoon. Studies by Wang et al. (2008), Lin et al. (2009), and Zhao et al. (2010) reported that the increasing clouds associated with the EASM rainfall suppress photochemical production of $\mathrm{O}_{3}$ by altering solar radiation, which also contributes to the minimum $\mathrm{O}_{3}$ concentrations in summer.

The strength of the EASM exhibits large interannual variations as a result of the interactions between the atmosphere and oceans (Webster et al., 1998). No previous studies, to our knowledge, have systematically examined the impacts of the EASM on interannual variations of summertime $\mathrm{O}_{3}$ in China. Recently, Zhou et al. (2013) analyzed 2000-2010 ozonesonde data from Hong Kong and found a close link between lower tropospheric $\mathrm{O}_{3}$ and the East Asian monsoon on interannual scales, but their analyses were focused on $\mathrm{O}_{3}$ in Hong Kong in spring and autumn. We present here a study to examine the impacts of the EASM on interannual variations of summertime surface-layer $\mathrm{O}_{3}$ concentrations over China, based on 1986-2006 simulations of $\mathrm{O}_{3}$ concentrations using the global chemical transport model GEOS (Goddard Earth Observing System)-Chem driven by the assimilated meteorological fields. This work is a companion study to the work of Zhu et al. (2012), which investigated the impacts of the EASM on interannual to decadal variations of summertime aerosols in China.

The GEOS-Chem model and numerical experiments are described in Sect. 2. Section 3 presents simulated interannual variations of summertime $\mathrm{O}_{3}$ in China. Section 4 shows simulated impacts of the EASM on interannual variations of summertime $\mathrm{O}_{3}$, and Sect. 5 examines the mechanisms through which the EASM influences the interannual variations. Section 6 compares the impacts of changing monsoon strength with those of changing anthropogenic emissions on $\mathrm{O}_{3}$ concentrations in China.

\section{Model description and experimental design}

\subsection{GEOS-Chem model}

We simulate tropospheric $\mathrm{O}_{3}$ using the global chemical transport model GEOS-Chem (version 8.2.1, http://acmg.seas. harvard.edu/geos) driven by the assimilated meteorological fields from the Goddard Earth Observing System of the NASA Global Modeling and Assimilation Office (GMAO). The version of the model used here has a horizontal resolution of $2^{\circ}$ latitude by $2.5^{\circ}$ longitude and 30 vertical layers from the surface to $0.01 \mathrm{hPa}$. The GEOS-Chem model includes a fully coupled treatment of tropospheric $\mathrm{O}_{3}-\mathrm{NO}_{\mathrm{x}}-$ VOC (volatile organic compound) chemistry and aerosol components. Tropospheric $\mathrm{O}_{3}$ is simulated with about 80 species and over 300 chemical reactions (Bey et al., 2001). Photolysis rates are computed using the fast-J algorithm (Wild et al., 2000). The cross-tropopause $\mathrm{O}_{3}$ flux in this version of GEOS-Chem is specified with the synthetic ozone ("synoz") method (McLinden et al., 2000) as implemented by Bey et al. (2001), which includes a passive, ozone-like tracer released into the stratosphere at a constant rate equivalent to that of the prescribed cross-tropopause ozone flux of $499 \mathrm{Tg} \mathrm{O}_{3} \mathrm{yr}^{-1}$.

\subsection{Emissions}

Global emissions of $\mathrm{O}_{3}$ precursors, aerosol precursors, and aerosols in the GEOS-Chem model follow Park et al. (2003, 2004), but anthropogenic emissions of $\mathrm{NO}_{\mathrm{x}}, \mathrm{CO}, \mathrm{SO}_{2}$, and $\mathrm{NH}_{3}$ over East Asia are overwritten by the emissions inventory of Streets et al. (2003). Global anthropogenic emissions of nonmethane hydrocarbons are from the GEIA (Global Emissions Inventory Activity) inventory (Piccot et al., 1992). Biomass burning emissions are taken from the GFED-2 inventory (van der Werf et al., 2006). These inventories are then scaled for 2005 on the basis of economic data and energy statistics as described by van Donkelaar et al. (2008). The biogenic emissions in the GEOS-Chem model are simulated using the MEGAN module (Model of Emissions of Gases and Aerosols from Nature; Guenther et al., 2006; Wiedinmyer et al., 2007). Soil $\mathrm{NO}_{\mathrm{x}}$ emissions are computed using a modified version of the algorithm proposed by Yienger and Levy (1995). Lightning emissions follow Price and Rind (1992), with the $\mathrm{NO}_{\mathrm{x}}$ vertical profile proposed by Pickering et al. (1998).

The simulations of tropospheric $\mathrm{O}_{3}$ by the GEOS-Chem model have been evaluated in previous studies for the United States (Fiore et al., 2005; Wu et al., 2008; H. Wang et al., 
2009) and China (Y. Wang et al., 2008, 2011; Jeong and Park, 2013; Lou et al., 2014). The model was found to be able to capture the magnitude and spatial distribution of $\mathrm{O}_{3}$ in China.

\subsection{Experiments}

In this study concentrations of $\mathrm{O}_{3}$ in China for years 19862006 are simulated using the GEOS-4 meteorological fields. To identify the key processes that influence $\mathrm{O}_{3}$ concentrations in different monsoon years, we perform the following simulations:

1. $\mathrm{O}_{3}$ TOT: the standard simulation of $\mathrm{O}_{3}$ concentrations for years 1986-2006. Global anthropogenic and biomass burning emissions of $\mathrm{NO}_{\mathrm{x}}, \mathrm{CO}$, nonmethane hydrocarbons, aerosols and aerosol precursors are fixed at year 2005 levels. Meteorological fields are allowed to vary over 1986-2006. The cross-tropopause $\mathrm{O}_{3}$ flux is set to $499 \mathrm{Tg} \mathrm{yr}^{-1}$ using the synoz scheme.

2. $\mathrm{O}_{3}$ TB: the sensitivity simulation of $\mathrm{O}_{3}$ concentrations for years 1986-2006 to quantify the role of transboundary transport of $\mathrm{O}_{3}$ in different monsoon years. The model setups are the same as those in $\mathrm{O}_{3}$ TOT except that all natural and anthropogenic emissions in China are turned off.

3. $\mathrm{O}_{3} \_\mathrm{ST}$ : the sensitivity simulation of $\mathrm{O}_{3}$ concentrations for years 1986-2006 to quantify the impact of crosstropopause $\mathrm{O}_{3}$ flux on surface-layer $\mathrm{O}_{3}$ concentrations. The model setups are the same as those in $\mathrm{O}_{3}$ TOT except that natural and anthropogenic emissions are turned off globally.

4. $\mathrm{O}_{3}$ EMIS: the sensitivity simulations to compare the impacts of changing anthropogenic emissions with those of changing monsoon strength. Two sensitivity simulations are conducted with 1986 and 2006 anthropogenic emissions, respectively. The emissions in year 1986 are simulated using the default scaling factors in the model (van Donkelaar et al., 2008). Year 2006 meteorological parameters are used to drive both simulations. The cross-tropopause $\mathrm{O}_{3}$ flux is set to $499 \mathrm{Tg} \mathrm{yr}^{-1}$ using the synoz scheme.

\subsection{East Asian summer monsoon index}

The interannual variations in strength of the EASM are commonly represented by the EASM index (EASMI). The EASMI introduced by Li and Zeng (2002) is used in this study. The formulation for calculating EASMI based on the GEOS-4 meteorological parameters was given in Zhu et al. (2012). Positive values of EASMI indicate strong monsoon years whereas negative values indicate weak monsoon years. Physically, a strong summer monsoon in China is characterized by strong southerlies extending from southern China to northern China, a deficit of rainfall in the middle and lower reaches of the Yangtze River, and large rainfall in northern China. On the contrary, in a weak summer monsoon year, China experiences weak southerlies, large rainfall in southern China, and a deficit of rainfall in northern China. The movement of the rain belts is associated with the strength of the southerlies.

\section{Simulated interannual variations of summertime $\mathrm{O}_{3}$ in China}

Figure 1a shows the simulated spatial distribution of JuneJuly-August (JJA) surface-layer $\mathrm{O}_{3}$ concentrations averaged over the period 1986-2006 from the $\mathrm{O}_{3}$ TOT simulation. Over eastern China, simulated $\mathrm{O}_{3}$ concentrations are 5065 ppbv in northern China and 25-50 ppbv in southern China. Such pattern of higher $\mathrm{O}_{3}$ concentrations in northern China than in southern China results from strong southerlies bringing clean air from the oceans to southern China during the summer monsoon season (Chan et al., 1998; Yamaji et al., 2006; Li et al., 2007; He et al., 2008; Wang et al., 2011). In western China, simulated $\mathrm{O}_{3}$ exhibits maximum concentrations of 65 ppbv. Our simulated surface-layer concentrations of $\mathrm{O}_{3}$ are high in both western and eastern China, which agree with the modeling studies of Wang et al. (2011), Jeong and Park (2013), and Lou et al. (2014). The high $\mathrm{O}_{3}$ concentrations in western China are associated with the downward transport of $\mathrm{O}_{3}$ from the stratosphere to troposphere (Wild and Akimoto, 2001; T. Wang et al. 2006a; Ding and Wang, 2006), and the high $\mathrm{O}_{3}$ concentrations in eastern China result from anthropogenic emissions (Wang et al., 2011).

The interannual variations in simulated $\mathrm{JJA} \mathrm{O}_{3}$ concentrations can be quantified by mean absolute deviation (MAD) and absolute percent departure from the mean (APDM) defined as MAD $=\frac{1}{n} \sum_{i=1}^{n}\left|P_{i}-\frac{1}{n} \sum_{i=1}^{n} P_{i}\right|$ and $\operatorname{APDM}=100 \% \times \mathrm{MAD} /\left(\frac{1}{n} \sum_{i=1}^{n} P_{i}\right)$, where $P_{i}$ is the simulated JJA mean $\mathrm{O}_{3}$ concentration of year $i$, and $n$ is the number of years examined ( $n=21$ for years 1986-2006). Therefore MAD represents the absolute interannual variation and APDM represents the interannual variation relative to the average of $\mathrm{O}_{3}$ concentration over the $n$ years. The MAD values of JJA surface-layer $\mathrm{O}_{3}$ concentrations (Fig. 1b) are 1.0-4.0 ppbv in China, with the largest values exceeding 2 ppbv found over northeastern China, coastal areas of southern China, and the Tibetan Plateau. As shown in Fig. 1c, the APDM values are in the range of 2-5\% over central eastern China where summer monsoon prevails, $1-3 \%$ in northwestern China, and 5-10\% over the Tibetan Plateau as well as the border and coastal areas of southern China. These interannual variations in $\mathrm{O}_{3}$ are significant as compared to the impacts of reductions in emissions of $\mathrm{O}_{3}$ precursors. Han et al. (2005) showed by modeling studies that, in eastern China, reductions in $\mathrm{NO}_{\mathrm{x}}$ or total VOCs (anthropogenic plus 
biogenic VOCs) by $50 \%$ lead to changes in $\mathrm{JJA} \mathrm{O}_{3}$ concentrations by $10-20 \%$.

The GEOS-Chem simulations of present-day surface-layer $\mathrm{O}_{3}$ concentrations in China have been evaluated in Wang et al. (2011) and Lou et al. (2014). Wang et al. (2011) demonstrated that the model captured well the magnitude and seasonal variation of surface-layer concentrations and column burdens of $\mathrm{O}_{3}$ in China. Lou et al. (2014) reported that the simulated $\mathrm{O}_{3}$ in China agreed fairly well with measurements collected from the literature with an average high bias of $9 \%$. Because of the lack of long-term $\mathrm{O}_{3}$ measurements in China, we evaluate the simulated interannual variations of JJA surface-layer $\mathrm{O}_{3}$ concentrations at two sites (Fig. 2): Hok Tsui in Hong Kong $\left(22^{\circ} 13^{\prime} \mathrm{N}, 114^{\circ} 15^{\prime} \mathrm{E}\right)$ and Ryori in Japan $\left(39^{\circ} 03^{\prime} \mathrm{N}, 144^{\circ} 82^{\prime} \mathrm{E}\right)$. The measurements at Hok Tsui are taken from T. Wang et al. (2009), and those at the Ryori site are from the WMO (World Meteorological Organization) World Data Center for Greenhouse Gases (WDCGG, http: //http://ds.data.jma.go.jp/gmd/wdcgg/). At Hok Tsui, simulated $\mathrm{O}_{3}$ concentrations are higher than the observations in JJA. This discrepancy may be due to the model's overestimation of $\mathrm{O}_{3}$ in marine boundary layers in summer (Liu et al., 2006). Interannually, the model captures well the peaks and troughs of the observed $\mathrm{JJA} \mathrm{O}_{3}$ concentrations, with a high correlation coefficient of +0.87 . The model underestimates $\mathrm{JJA} \mathrm{O}_{3}$ concentrations at Ryori, probably due to the uncertainties with local emissions, but captures mostly the years with maximum or minimum $\mathrm{O}_{3}$ levels with a correlation coefficient of +0.47 . The simulated APDM values at Hok Tsui and Ryori are both $7 \%$, smaller than the observed interannual variations of 22 and $8 \%$ at these two sites, respectively, which can be attributed to the fixed anthropogenic emissions of $\mathrm{O}_{3}$ precursors in our $\mathrm{O}_{3}$ TOT simulation.

\section{Impacts of the EASM on interannual variations of summertime $\mathrm{O}_{3}$ in China}

The simulated JJA surface-layer $\mathrm{O}_{3}$ concentration averaged over all of China (defined by the national borders of China) is shown in Fig. 3a for years 1986-2006 based on the $\mathrm{O}_{3}$ TOT simulation. Summertime $\mathrm{O}_{3}$ concentrations show large interannual variations, with high (or low) $\mathrm{O}_{3}$ concentrations in strong (or weak) monsoon years. Concentrations of $\mathrm{O}_{3}$ are found to correlate positively with the EASMI; the correlation coefficient is +0.75 and is statistically significant at the 95th percentile. The spatial distribution of the correlation coefficients between the EASMI and $\mathrm{O}_{3}$ concentrations from the $\mathrm{O}_{3}$ TOT simulation is presented in Fig. 3b. Positive correlations are found in almost all of China, and large positive correlation coefficients that exceed +0.5 are found over the region between 90 and $110^{\circ} \mathrm{E}$. Since anthropogenic emissions of $\mathrm{O}_{3}$ precursors are kept unchanged in the simulation for years 1986-2006, these strong positive correlations
(a) $\mathrm{O}_{3}$ Conc. (ppbv)

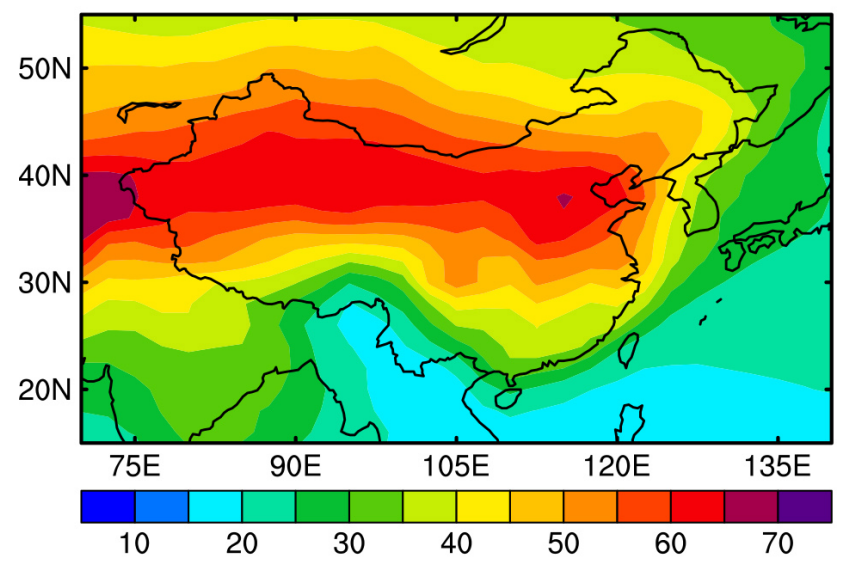

(b) MAD (ppbv)

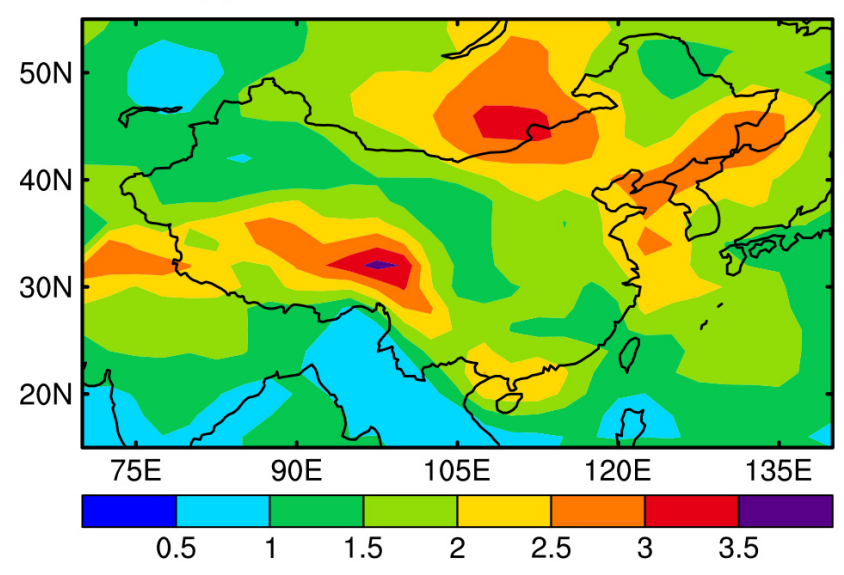

(c) APDM (\%)

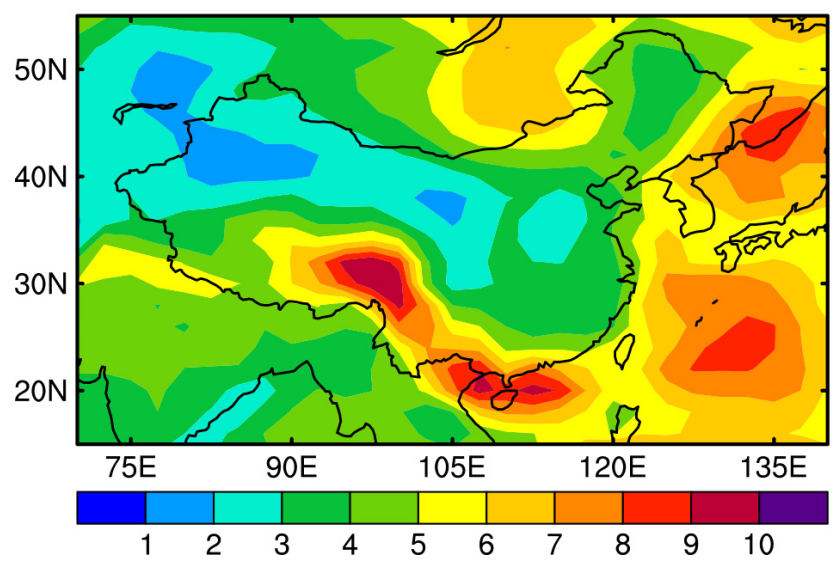

Figure 1. (a) Simulated JJA surface-layer $\mathrm{O}_{3}$ concentrations (ppbv) that are averaged over years 1986-2006 of simulation $\mathrm{O}_{3}$ TOT. (b) MAD (ppbv) and (c) APDM (\%) calculated with the 1986-2006 simulation of $\mathrm{O}_{3}$ in $\mathrm{O}_{3}$ TOT. 

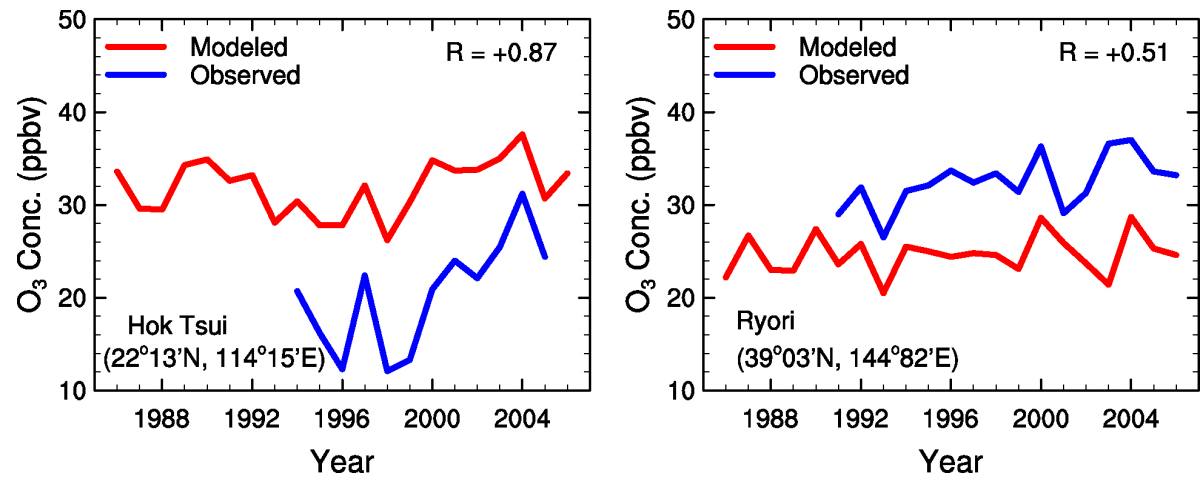

Figure 2. Comparisons of observed and simulated JJA mean surface-layer $\mathrm{O}_{3}$ concentrations at Hok Tsui $\left(22^{\circ} 13^{\prime} \mathrm{N}, 114^{\circ} 15^{\prime} \mathrm{E}\right)$ in $\mathrm{Hong}$ Kong (left) and Ryori ( $\left.39^{\circ} 03^{\prime} \mathrm{N}, 144^{\circ} 82^{\prime} \mathrm{E}\right)$ in Japan (right). Correlation coefficient between simulations and observations is shown in the top-right corner of each panel, which is calculated over the time period with observations available.

demonstrate that the EASM strength has large impacts on $\mathrm{JJA} \mathrm{O}_{3}$ concentrations over China.

In order to quantify the impacts of the EASM on $\mathrm{O}_{3}$ concentrations over China, we show in Fig. $4 \mathrm{a}$ and b, respectively, the absolute and percentage differences between $\mathrm{O}_{3}$ concentrations averaged over the five weakest EASM years $(1988,1989,1996,1998$, and 2003) and those averaged over the five strongest EASM years (1990, 1994, 1997, 2002, and 2006). These weakest (or strongest) monsoon years are selected within years 1986-2006 based on the five largest negative (or positive) values of the normalized EASMI as shown in Fig. 3a. Relative to the concentrations in the strongest monsoon years, $\mathrm{O}_{3}$ levels in the weakest monsoon years are lower over almost all of China, with the largest reductions exceeding $3 \mathrm{ppbv}$ (or $6 \%$ ) in northeastern and southwestern China and over or near the Tibetan Plateau. Concentrations of $\mathrm{O}_{3}$ in the weakest monsoon years are simulated to be higher than those in the strongest monsoon years by $3-5$ ppbv (or 6$15 \%)$ over the East China Sea. The pattern of the differences in $\mathrm{O}_{3}$ concentrations agrees with the spatial distribution of the correlation coefficients (Fig. 3b). Averaged over China, the $\mathrm{O}_{3}$ level in the weakest monsoon years is lower than that in the strongest monsoon years by $2.0 \mathrm{ppbv}$ (or $4 \%$ ). Note that the monsoon region covers almost all of China except the northwest (Gao, 1962; An et al., 2000). Our simulated monsoon-induced changes in $\mathrm{O}_{3}$ in China (Fig. 4) are mostly within the monsoon region. The changes in $\mathrm{O}_{3}$ over Siberia are large, which can be explained by the anomalous northerlies over the north border of China between the five weakest and strongest EASM years (weakest-strongest) (Fig. 5) that transport $\mathrm{O}_{3}$ to China.

Figure $4 \mathrm{c}$ and $\mathrm{d}$ are pressure-longitude plots of the differences in $\mathrm{O}_{3}$ averaged over the latitude range of $20-46^{\circ} \mathrm{N}$. From the surface to $250 \mathrm{hPa}$ altitude, $\mathrm{O}_{3}$ levels in the weakest monsoon years are lower by up to $5 \mathrm{ppbv}$ (or $8 \%$ ) over $80-115^{\circ} \mathrm{E}$ and are higher by $1-3$ ppbv (or 3-6\%) over 120 $135^{\circ} \mathrm{E}$ relative to the concentrations in the strongest monsoon years. Concentrations of $\mathrm{O}_{3}$ at $130-250 \mathrm{hPa}$ altitudes (a) EASMI \& Surface $\mathrm{O}_{3}$ Conc.

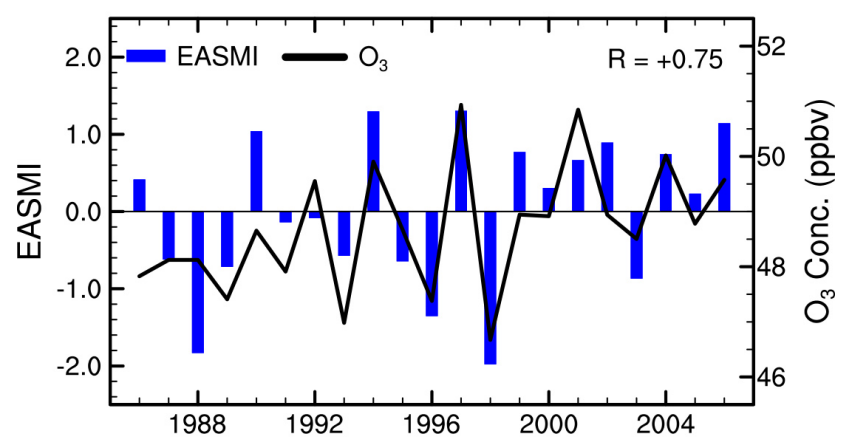

(b) Corr. EASMI \& Surface $\mathrm{O}_{3}$ Conc.

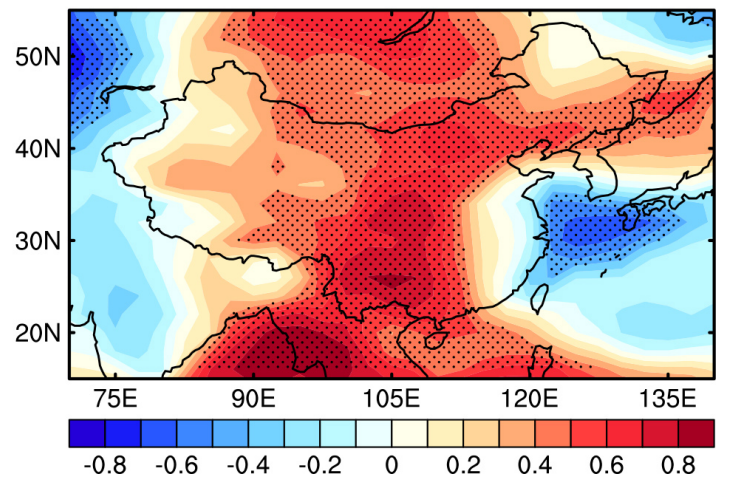

Figure 3. (a) The normalized time series of EASMI (blue bars, left $y$ axis) and the simulated JJA surface-layer $\mathrm{O}_{3}$ concentrations (black line, right $y$ axis, ppbv) averaged over China for years of 1986-2006. (b) Spatial distribution of the correlation coefficients between the EASMI and the JJA surface-layer $\mathrm{O}_{3}$ concentrations. The dotted areas indicate statistical significance with $95 \%$ confidence from a two-tailed Student's $t$ test. The EASMI are calculated using the GEOS-4 assimilated meteorological data. 
(a) Diff. in $\mathrm{O}_{3}$ Conc. (ppbv)

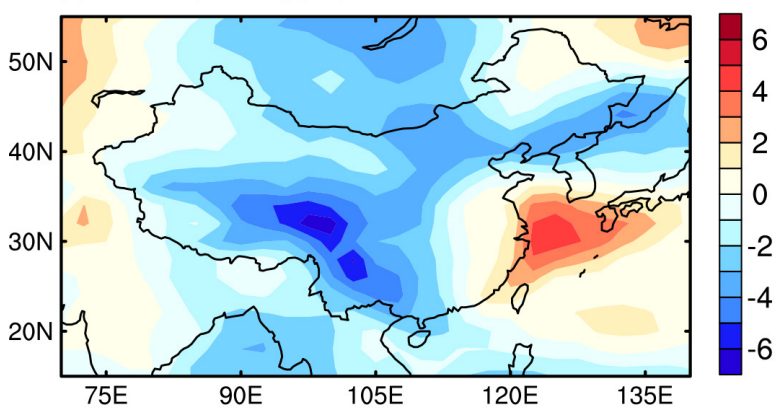

(b) Diff. in $\mathrm{O}_{3}$ Conc. (\%)

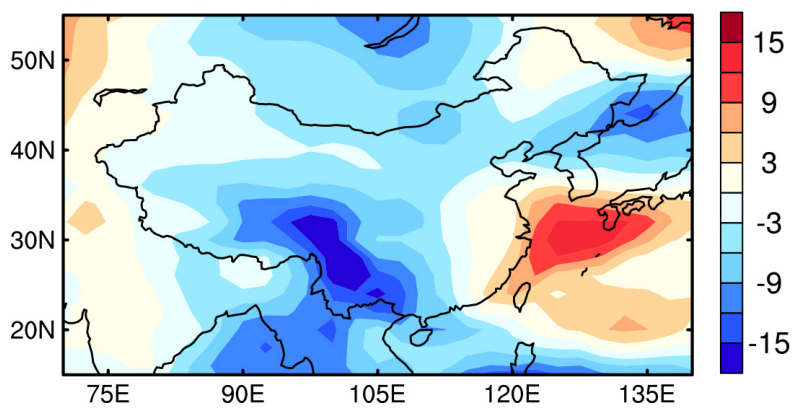

(c) Diff. in $\mathrm{O}_{3}$ Conc. (ppbv)

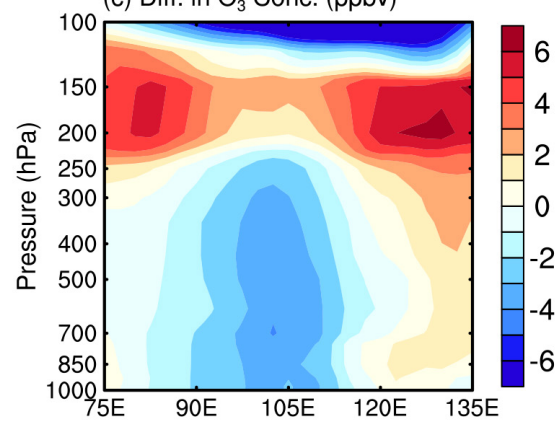

(d) Diff. in $\mathrm{O}_{3}$ Conc. (\%)

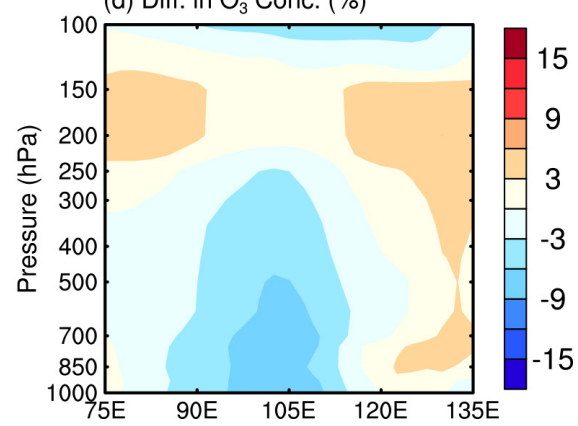

Figure 4. Horizontal distributions of (a) absolute and (b) percentage differences in JJA surface-layer $\mathrm{O}_{3}$ concentrations between the five weakest and strongest EASM years (weakest-strongest). Pressure-longitude cross sections averaged over $20-46^{\circ} \mathrm{N}$ for (c) absolute and (d) percentage differences in JJA O 3 concentrations between the five weakest and strongest EASM years (weakest-strongest). Results are from simulation $\mathrm{O}_{3}$ TOT and the unit is shown on top of each panel.

(a) UV at $850 \mathrm{hPa}\left(\mathrm{m} \mathrm{s}^{-1}\right)$

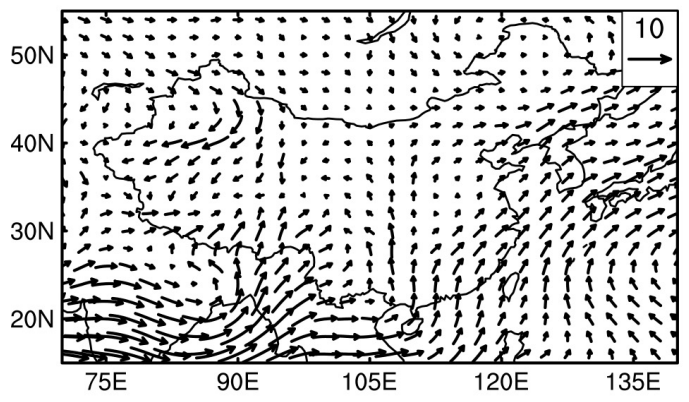

(c) Diff. in UV at $850 \mathrm{hPa}\left(\mathrm{m} \mathrm{s}^{-1}\right)$

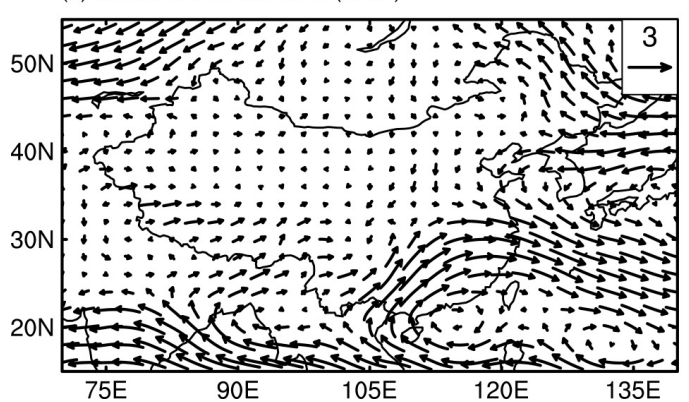

(b) UV at $500 \mathrm{hPa}\left(\mathrm{m} \mathrm{s}^{-1}\right)$

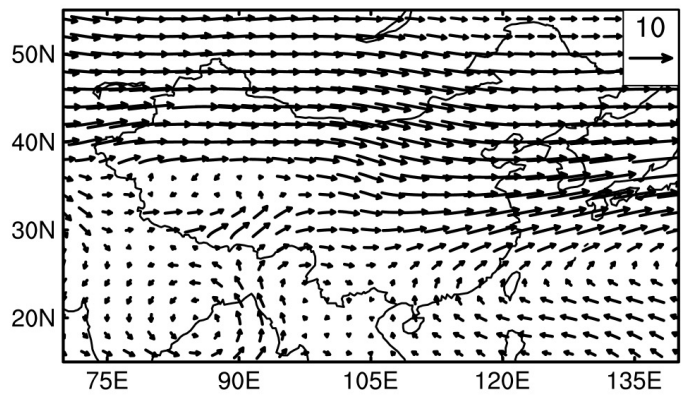

(d) Diff. in UV at $500 \mathrm{hPa}\left(\mathrm{m} \mathrm{s}^{-1}\right)$

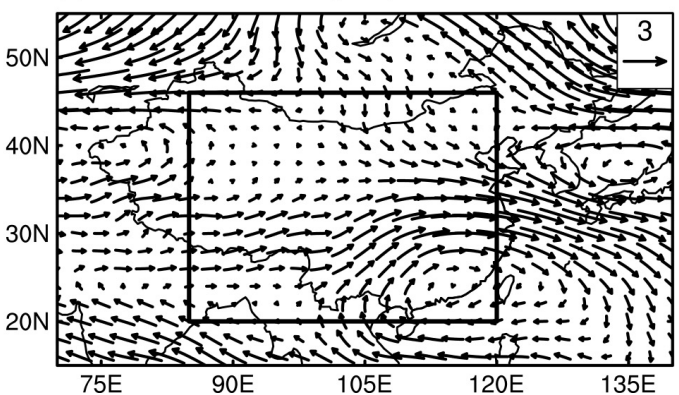

Figure 5. The JJA mean horizontal winds at (a) 850 and (b) $500 \mathrm{hPa}$ averaged over years 1986-2006. The composite differences in horizontal winds between the five weakest and strongest EASM years (weakest-strongest) at (c) 850 and (d) $500 \mathrm{hPa}$. Horizontal winds are from the GEOS-4 assimilated meteorological data. Unit is shown on top of each panel. The location of box $\left(85-120^{\circ} \mathrm{E}, 20-46^{\circ} \mathrm{N}\right.$, the surface to $250 \mathrm{hPa}$ ) selected to capture the features of transboundary $\mathrm{O}_{3}$ transport is also shown in (d). 
exhibit increases in the weakest monsoon years, with maximum increases of 4-7 ppbv (3-6\%) over 80 and $130^{\circ} \mathrm{E}$, as a result of the anomalous horizontal convergence at these layers.

\section{Mechanisms of the impacts of the EASM on summertime $\mathrm{O}_{3}$}

\subsection{Impacts of the EASM on transboundary transport of $\mathrm{O}_{3}$}

Considering that $\mathrm{O}_{3}$ concentrations in almost all of China are lower in the weakest monsoon years than in the strongest monsoon years and that tropospheric $\mathrm{O}_{3}$ has a relatively long lifetime of 3-4 weeks (Seinfeld and Pandis, 2006), we examine firstly the impacts of the EASM on transboundary transport of $\mathrm{O}_{3}$. Figure 5 shows JJA horizontal winds at 850 and $500 \mathrm{hPa}$ averaged over years 1986-2006 as well as the composite differences in JJA horizontal winds between the five weakest and five strongest EASM years at these two layers. The typical features in winds during the EASM can be seen in Figs. 5a and b. The southerlies prevail in southeastern China in the lower and middle troposphere in JJA. Figure 5c and $d$ also present the differences in winds between the weakest and strongest EASM years (weakest minus strongest). In JJA, anomalous southerlies are found in southern China and anomalous westerlies are found in southeastern China, as the winds in the five weakest monsoon years are compared with those in the five strongest monsoon years. Such differences in winds between weak and strong EASM years were also reported in Li and Zeng (2002) and Huang (2004).

The differences in winds in different monsoon years lead to differences in transboundary transport of $\mathrm{O}_{3}$. We show in Fig. 6 the differences in simulated horizontal mass fluxes of $\mathrm{O}_{3}$ at the four lateral boundaries of the selected box (85$120^{\circ} \mathrm{E}, 20-46^{\circ} \mathrm{N}$, from the surface to $250 \mathrm{hPa}$ ) and in Table 1 the summary of the composite analysis on fluxes of $\mathrm{O}_{3}$ in and out of this box, based on simulation $\mathrm{O}_{3}$ TOT. This box is selected to capture the features of transboundary $\mathrm{O}_{3}$ transport that influence $\mathrm{O}_{3}$ concentrations in China. The location of the box is shown in Fig. 5d. Relative to the strongest monsoon years, the weakest monsoon years have less inflow by $0.1 \mathrm{Tg}$ season $^{-1}$ at the west boundary, larger inflow fluxes of $\mathrm{O}_{3}$ by $4.2 \mathrm{Tg}$ season $^{-1}$ at the south boundary and by $5.5 \mathrm{Tg}$ season $^{-1}$ at the north boundary, and larger outflow by $12.9 \mathrm{Tg}$ season $^{-1}$ at the east boundary (Table 1 , Fig. 6), as mass fluxes are summed over JJA. The net effect is a larger transboundary outflow of $\mathrm{O}_{3}$ by $3.3 \mathrm{Tg}_{\text {season }}{ }^{-1}$ in the weakest monsoon years than in the strongest monsoon years. The anomalous westerlies in southeastern China are especially important, which bring polluted air with high $\mathrm{O}_{3}$ concentrations to the coastal areas and the East China Sea (Fig. 6d), leading to reductions in $\mathrm{O}_{3}$ concentration in China.
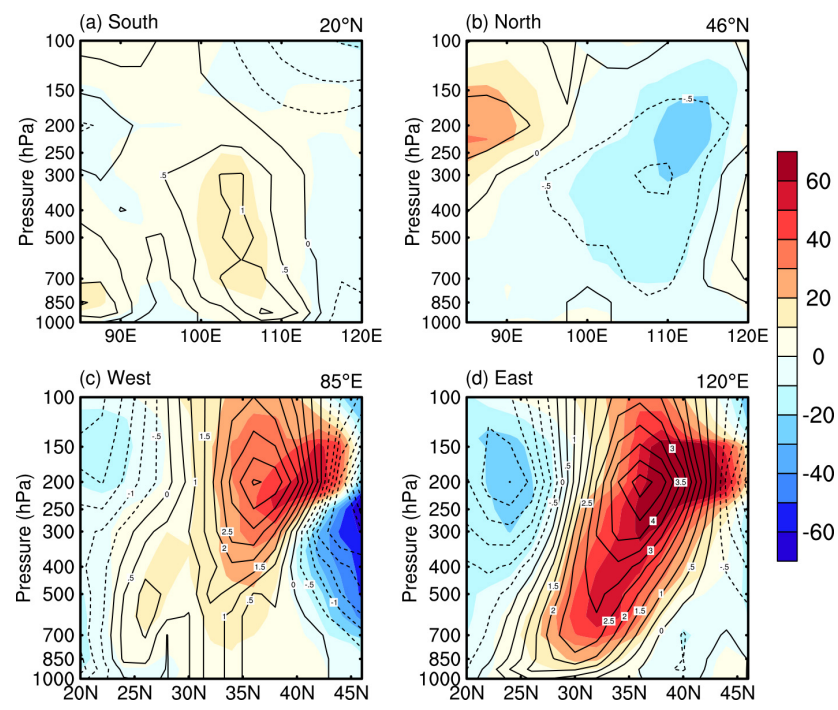

Figure 6. The composite differences in horizontal $\mathrm{O}_{3}$ fluxes (shades, $\mathrm{kg} \mathrm{s}^{-1}$ ) and winds (contours, $\mathrm{m} \mathrm{s}^{-1}$ ) at the (a) south, (b) north, (c) west, and (d) east boundaries of the selected box (85$120^{\circ} \mathrm{E}, 20-46^{\circ} \mathrm{N}$, from the surface to $250 \mathrm{hPa}$ ) between the five weakest and strongest EASM years (weakest-strongest). Fluxes and winds that are eastward or northward are positive, and those that are westward and southward are negative. Mass fluxes are from simulation $\mathrm{O}_{3}$ TOT. Longitudinal and meridional winds are from the GEOS-4 assimilated meteorological data.

The role of changes in transboundary transport of $\mathrm{O}_{3}$ can be further quantified by the simulation $\mathrm{O}_{3}$ TB with natural and anthropogenic emissions of $\mathrm{O}_{3}$ precursors in China turned off. The spatial distribution of $\mathrm{O}_{3}$ from simulation $\mathrm{O}_{3} \mathrm{~TB}$ (referred to as $\mathrm{TBO}_{3}$ hereafter) is presented in Fig. $7 \mathrm{a} . \mathrm{TBO}_{3}$ concentrations show a distinct spatial gradient over China, decreasing from about $55 \mathrm{ppbv}$ in northwestern China to about $10 \mathrm{ppbv}$ in southeastern China. The JJA $\mathrm{TBO}_{3}$ concentration averaged over the whole China is $30 \mathrm{ppbv}$, which is about $62 \%$ of the average concentration simulated in $\mathrm{O}_{3}$ TOT, indicating that a significant fraction of surface-layer $\mathrm{O}_{3}$ over China is from transboundary transport. The differences in $\mathrm{TBO}_{3}$ concentrations between the weakest and strongest monsoon years (Fig. 7d) are, to a large extent, similar to those from simulation $\mathrm{O}_{3}$ TOT (Fig. 4a), in terms of both distributions and magnitudes. Averaged over China, the difference in $\mathrm{TBO}_{3}$ between the weakest and strongest monsoon years is $-1.6 \mathrm{ppbv}$, which accounts for $80 \%$ of the corresponding difference obtained in $\mathrm{O}_{3}$ TOT. The JJA mass fluxes of TBO3 for the selected box $\left(85-120^{\circ} \mathrm{E}, 20-46^{\circ} \mathrm{N}\right.$, from the surface to $250 \mathrm{hPa}$ ) are also similar to those simulated in $\mathrm{O}_{3}$ TOT (Table 1), with a net horizontal outflow of $2.8 \mathrm{Tg}$ season $^{-1}$. These model results indicate that the differences in transboundary transport of $\mathrm{O}_{3}$ is a dominant mechanism through which the EASM influences interannual variations of $\mathrm{JJA} \mathrm{O}_{3}$ concentrations in China. 


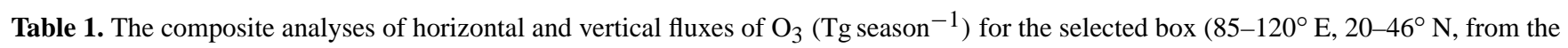
surface to $250 \mathrm{hPa}$ ) based on simulations $\mathrm{O}_{3}$ TOT and $\mathrm{O}_{3}$ TB. The values are averaged over the five weakest $(1988,1989,1996,1998$, and 2003) and five strongest monsoon years (1990, 1994, 1997, 2002, and 2006), and the differences are calculated as (weakest-strongest). For horizontal fluxes, positive values indicate eastward or northward transport and negative values indicate westward or southward transport. For vertical fluxes, positive values indicate upward transport.

\begin{tabular}{lrrr|rrr}
\hline Side of the selected box & \multicolumn{3}{c|}{$\mathrm{O}_{3}$ TOT } & \multicolumn{3}{c}{$\mathrm{O}_{3}$ TB } \\
\hline & Weakest & Strongest & Difference & Weakest & Strongest & Difference \\
\cline { 2 - 7 } & \multicolumn{3}{c}{ Horizontal mass fluxes } \\
\hline West & +83.7 & +83.8 & -0.1 & +78.8 & +78.9 & -0.1 \\
East & +106.5 & +93.5 & +12.9 & +84.1 & +73.1 & +11.0 \\
South & +13.4 & +9.2 & +4.2 & +13.8 & +10.5 & +3.3 \\
North & -19.3 & -13.7 & -5.5 & -20.0 & -15.0 & -5.0 \\
\hline \multicolumn{7}{c}{ Vertical mass fluxes } \\
\hline Top & +22.1 & +20.7 & +1.4 & +16.5 & +15.5 \\
\hline
\end{tabular}
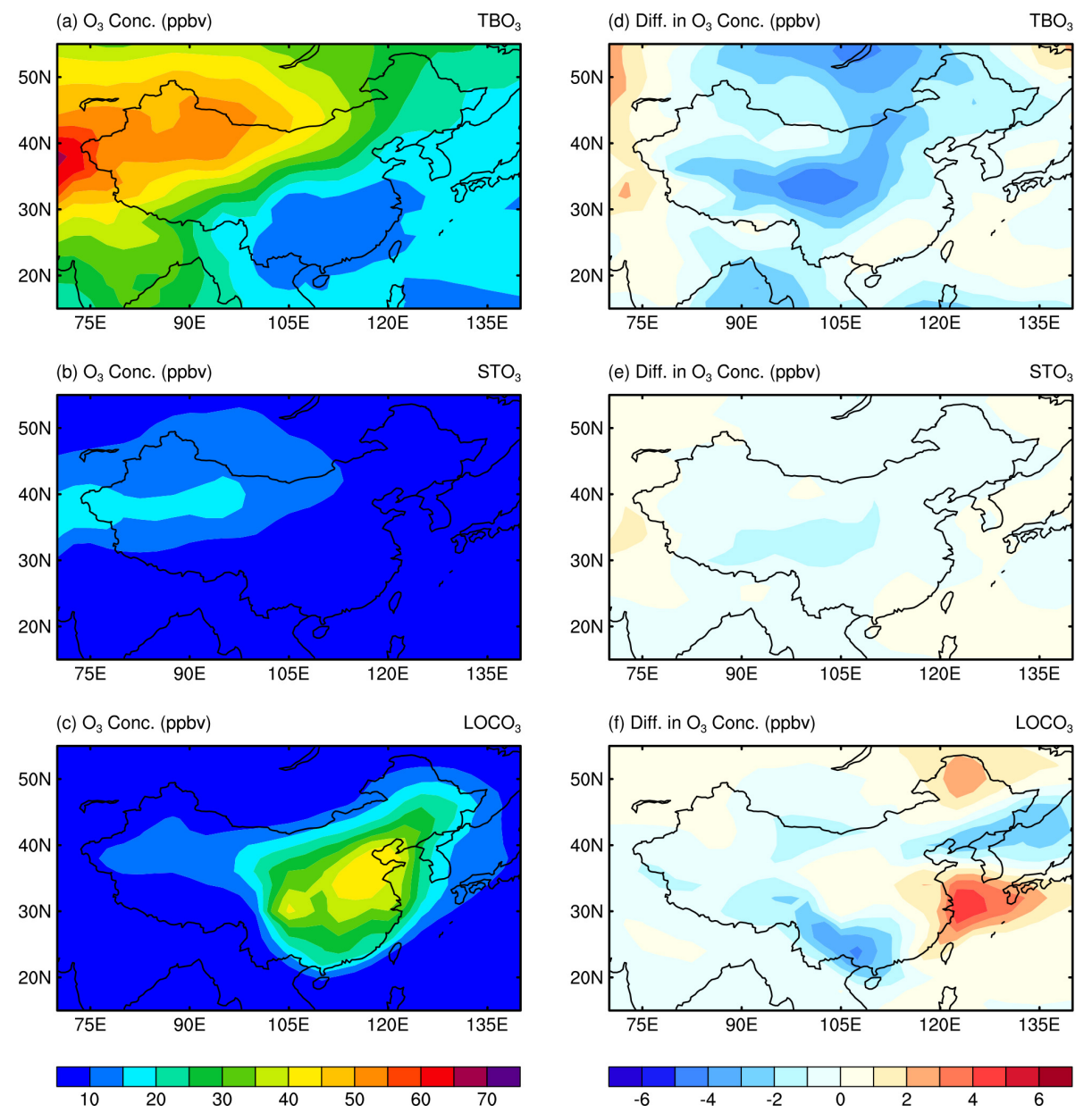

Figure 7. The JJA surface-layer $\mathrm{O}_{3}$ concentrations (ppbv) from (a) simulation $\mathrm{O}_{3}$ TB (referred to as $\mathrm{TBO}_{3}$ ), (b) simulation $\mathrm{O}_{3}$-ST (referred to as $\mathrm{STO}_{3}$ ), and (c) simulation $\mathrm{O}_{3}$ TOT minus simulation $\mathrm{O}_{3}$ TB (referred to as $\mathrm{LOCO}_{3}$ ). (a), (b), and (c) are the averages over years $1986-$ 2006. (d), (e), and (f) are the composite differences (ppbv) in $\mathrm{TBO}_{3}, \mathrm{STO}_{3}$, and $\mathrm{LOCO}_{3}$, respectively, between the five weakest and strongest EASM years (weakest-strongest). 


\subsection{Impacts of the EASM on vertical transport of $\mathrm{O}_{3}$}

Vertical circulations in China have some unique features during the EASM. In summer, two major ascending branches of winds (or strong convections) are observed throughout the entire troposphere (Fig. 8a). One branch is located over the Yangtze River valley, associated with the Mei-yu front (rain belt) of the EASM (Ding and Chan, 2005). The other branch is over the Tibetan Plateau, because the Tibetan Plateau during summer serves as a large heat source, which uplifts heated air to the upper troposphere and even to the stratosphere (Ye, 1981). Figure 8a shows JJA vertical velocity and simulated vertical mass flux of $\mathrm{O}_{3}$ at $500 \mathrm{hPa}$ averaged over years 1986-2006. Since vertical velocity is not available from the reanalyzed GEOS-4 meteorological fields, vertical winds presented here are from the NCEP/NCAR (National Centers for Environmental Prediction/National Center for Atmospheric Research) reanalysis data. The simulated mass fluxes are obtained in $\mathrm{O}_{3}$ TOT. The largest vertical mass fluxes of $\mathrm{O}_{3}$ are simulated to occur over northern China and western China where surface-layer $\mathrm{O}_{3}$ concentrations are high, and over the Tibetan Plateau and its surrounding areas as a result of the strong convections there.

Figure $8 \mathrm{~b}$ shows the differences in JJA vertical wind velocity and simulated vertical mass flux of $\mathrm{O}_{3}$ at $500 \mathrm{hPa}$ between the weakest and strongest monsoon years. Relative to the strongest monsoon years, anomalous convections are found over central and western China in the weakest monsoon years, leading to enhanced upward transport of $\mathrm{O}_{3}$ from the surface to upper troposphere at these locations. The differences in vertical winds shown in Fig. $8 \mathrm{~b}$ agree with those reported in Huang (2004).

Table 1 also summarizes the composite analysis on vertical fluxes of $\mathrm{O}_{3}$ through the top side of the selected box $\left(85-120^{\circ} \mathrm{E}, 20-46^{\circ} \mathrm{N}\right.$, from the surface to $\left.250 \mathrm{hPa}\right)$. In simulation $\mathrm{O}_{3}$ TOT, the upward flux of $\mathrm{O}_{3}$ through the top plane of the box in the weakest monsoon years is larger than that in the strongest monsoon years by $1.4 \mathrm{Tg} \mathrm{season}^{-1}$. This anomalous vertical outflow of $1.4 \mathrm{Tg}$ season $^{-1}$ is smaller than the anomalous horizontal transboundary outflow of 3.3 $\mathrm{Tg}$ season $^{-1}$ (Sect. 5.1), indicating that the differences in vertical transport of $\mathrm{O}_{3}$ also contribute to lower JJA $\mathrm{O}_{3}$ concentrations in China in the weakest monsoon years than in the strongest monsoon years, but the impact of the differences in vertical transport is smaller than that of the differences in transboundary transport of $\mathrm{O}_{3}$.

\subsection{Impact of cross-tropopause transport on surface-layer $\mathrm{O}_{3}$ concentrations}

The cross-tropopause transport of $\mathrm{O}_{3}$ from the stratosphere is an important source of tropospheric $\mathrm{O}_{3}$. Simulation $\mathrm{O}_{3}$ ST is performed to quantify the impact of cross-tropopause transport on JJA surface-layer $\mathrm{O}_{3}$ concentrations. The simulated JJA concentrations of $\mathrm{O}_{3}$ in simulation $\mathrm{O}_{3} \_\mathrm{ST}$ (referred to as (a) OMEGA \& $\mathrm{O}_{3}$ vertical mass flux at $500 \mathrm{hPa}$

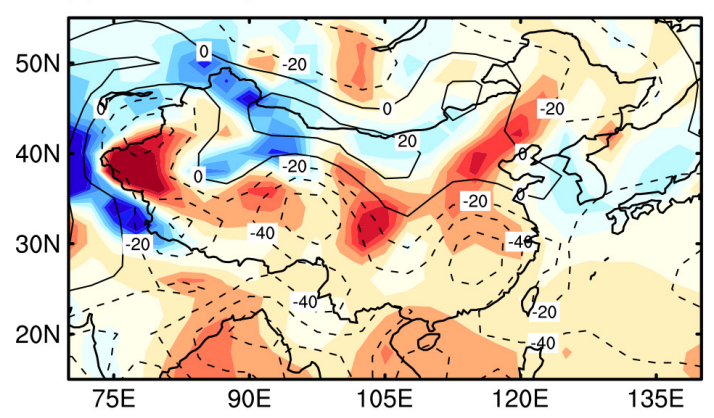

(b) Diff. in OMEGA \& $\mathrm{O}_{3}$ vertical mass flux at $500 \mathrm{hPa}$

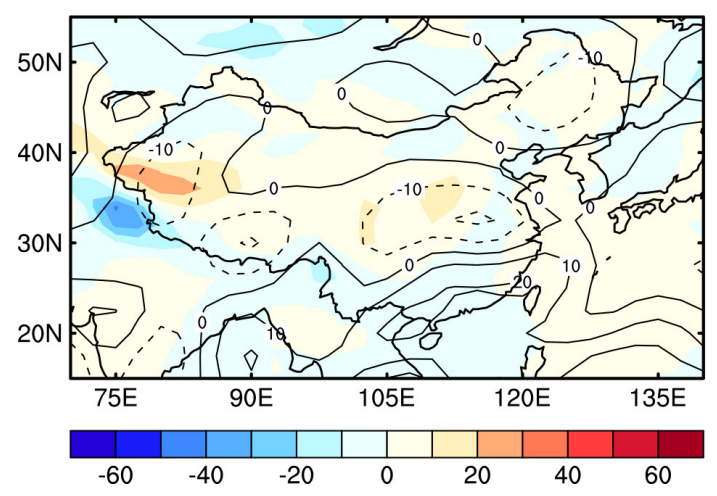

Figure 8. (a) The spatial distributions of JJA mean vertical wind velocity (contours, $\mathrm{Pa} \mathrm{s}^{-1} \cdot 1000$ ) and simulated upward mass flux of $\mathrm{O}_{3}$ (shades, $\mathrm{kg} \mathrm{s}^{-1}$ ) averaged over years 1986-2006. (b) The composite differences in vertical wind (contours, $\left.\mathrm{Pa} \mathrm{s}^{-1} \cdot 1000\right)$ and simulated upward mass flux of $\mathrm{O}_{3}$ (shades, $\mathrm{kg} \mathrm{s}^{-1}$ ) between the five weakest and strongest EASM years (weakest-strongest). Vertical winds are from the NCEP/NACR reanalysis data.

$\mathrm{STO}_{3}$ ) at the surface-layer averaged over years 1986-2006 are presented in Fig. 7b. $\mathrm{STO}_{3}$ shows maximum concentrations of 15-20 ppbv over northwestern China, contributing to the high $\mathrm{O}_{3}$ concentrations in western China simulated in $\mathrm{O}_{3}$ TOT. Averaged over China, the surface-layer concentration of JJA STO 3 is 8 ppbv, which is about $17 \%$ of that of JJA $\mathrm{O}_{3}$ simulated in $\mathrm{O}_{3}$ TOT. Concentrations of $\mathrm{STO}_{3}$ increase with altitude; the ratio of $\mathrm{STO}_{3}$ to $\mathrm{O}_{3}$ simulated in $\mathrm{O}_{3}$ TOT is about $50 \%$ at $200 \mathrm{hPa}$ and about $80 \%$ at $100 \mathrm{hPa}$. Figure 7e shows the differences in surface-layer $\mathrm{STO}_{3}$ concentrations between the weakest and strongest monsoon years. Relative to the strongest monsoon years, surface-layer $\mathrm{STO}_{3}$ concentrations are lower by $1-2$ ppbv over central China and the Tibetan Plateau in the weakest monsoon years. Averaged over China, the difference in $\mathrm{STO}_{3}$ between the weakest and strongest monsoon years is $-0.45 \mathrm{ppbv}$, which only accounts for $23 \%$ of the corresponding difference in $\mathrm{TOTO}_{3}$ and hence indicates that the variations in $\mathrm{O}_{3}$ transported from the stratosphere in different monsoon years are not the major factors that drive the interannual variations of JJA surface-layer $\mathrm{O}_{3}$ concentrations in China. Note that the crosstropopause $\mathrm{O}_{3}$ flux in $\mathrm{O}_{3}$ TOT and $\mathrm{O}_{3} \_\mathrm{ST}$ is specified with 
the synoz method (McLinden et al., 2000) with a constant cross-tropopause ozone flux of $499 \mathrm{Tg} \mathrm{O}_{3} \mathrm{yr}^{-1}$. The latest version of the GEOS-Chem model also has an option of using the linearized ozone ("linoz") parameterization scheme of McLinden et al. (2000) to represent $\mathrm{O}_{3}$ in the stratosphere, in which the ozone vertical profiles across the tropopause are relaxed back toward climatological profiles and hence cross-tropopause $\mathrm{O}_{3}$ flux varies with time step and location. We have tested using linoz instead of synoz and found that these two schemes obtain same conclusion about the impact of cross-tropopause $\mathrm{O}_{3}$ on JJA surface-layer $\mathrm{O}_{3}$ in China.

\subsection{Impacts of the EASM on local chemical production of $\mathrm{O}_{3}$}

The differences in $\mathrm{O}_{3}$ concentrations between $\mathrm{O}_{3}$ TOT and $\mathrm{O}_{3}$ TB simulations are attributed to the enhancement of $\mathrm{O}_{3}$ due to Chinese emissions, referred to as Chinese local $\mathrm{O}_{3}\left(\mathrm{LOCO}_{3}\right)$. Figure $7 \mathrm{c}$ shows that high concentrations of $\mathrm{LOCO}_{3}$ are located in eastern China where the emissions of $\mathrm{O}_{3}$ precursors are large. The maximum $\mathrm{LOCO}_{3}$ concentrations reach $40-45 \mathrm{ppbv}$. The $\mathrm{LOCO}_{3}$ concentration averaged over all of China is $18 \mathrm{ppbv}$, which is about $38 \%$ of the value simulated in $\mathrm{O}_{3}$ TOT. Figure $7 \mathrm{f}$ presents the differences in simulated $\mathrm{LOCO}_{3}$ between the weakest and strongest EASM years. Relative to the strongest monsoon years, $\mathrm{LOCO}_{3}$ concentrations in the weakest monsoon years are lower by 25 ppbv over southern China and slightly higher by up to 1 ppbv over central China. Averaged over China, the difference in $\mathrm{LOCO}_{3}$ between the weakest and strongest monsoon years is $-0.4 \mathrm{ppbv}$, which accounts for $20 \%$ of the corresponding difference in $\mathrm{TOTO}_{3}\left(\mathrm{O}_{3}\right.$ concentrations in simulation O3_TOT) and hence reflects the small impacts of monsoon strength on local chemical production of $\mathrm{O}_{3}$.

The small impacts of monsoon strength on local chemical production of $\mathrm{O}_{3}$ can be further justified by examining the net chemical production of $\mathrm{O}_{3}$ within the selected box $\left(85-120^{\circ} \mathrm{E}, 20-46^{\circ} \mathrm{N}\right.$, from the surface to $\left.250 \mathrm{hPa}\right)$. The sum over the selected box, the net chemical production (chemical production - chemical loss) averaged over the weakest monsoon years, is $39.0 \mathrm{Tg}$ season $^{-1}$ in JJA, which is smaller than that averaged over the strongest monsoon years by $0.5 \%$.

\section{Comparison of the impact of monsoon strength with the role of changing emissions}

We perform simulations $\mathrm{O}_{3}$ EMIS to compare the impact of changing monsoon strength (Sect. 4) with that of changing anthropogenic emissions on $\mathrm{JJA} \mathrm{O}_{3}$ concentrations. Two sensitivity simulations are conducted with 1986 and 2006 anthropogenic emissions, respectively, and year 2006 meteorological parameters are used to drive both simulations. Relative to 1986, year 2006 emissions of $\mathrm{NO}_{\mathrm{x}}, \mathrm{CO}$, and NMVOCs (non-methane volatile organic compounds) in China increase

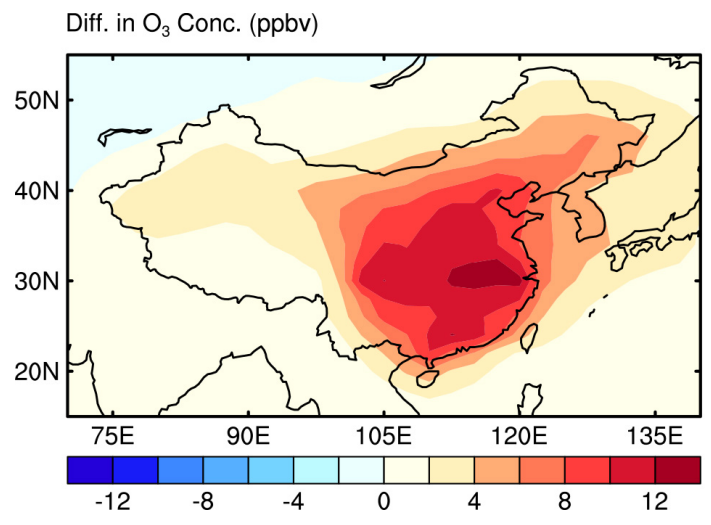

Figure 9. The changes in simulated JJA surface-layer $\mathrm{O}_{3}$ concentrations (ppbv) owing to the changes in anthropogenic emissions of $\mathrm{O}_{3}$ precursors over years 1986-2006, based on simulations of $\mathrm{O}_{3}$ EMIS.

by 111,56 , and $9 \%$, respectively, leading to increases in JJA surface-layer $\mathrm{O}_{3}$ by $9-15 \mathrm{ppbv}$ in southeastern China (Fig. 9). Note the locations of large increases in $\mathrm{O}_{3}$ here are different from those of large differences in $\mathrm{O}_{3}$ between the weakest and strongest monsoon years (Fig. 4b). Averaged over China, the change in JJA surface-layer $\mathrm{O}_{3}$ concentration owing to changes in emissions over years 19862006 is $+5.3 \mathrm{ppbv}$, which is larger than the difference in the JJA surface-layer $\mathrm{O}_{3}$ of $2.0 \mathrm{ppbv}$ between the selected weakest and strongest monsoon years. However, the difference in surface-layer $\mathrm{O}_{3}$ between the weak monsoon year 1998 and the strong monsoon year 1997 is $-4.2 \mathrm{ppbv}$, indicating that the impacts of the EASM on $\mathrm{JJA} \mathrm{O}_{3}$ can be particularly strong for certain years.

\section{Conclusions}

We examine the impacts of the East Asian summer monsoon (EASM) on interannual variations of summertime surfacelayer $\mathrm{O}_{3}$ concentrations over China using the GEOS-Chem model driven by the assimilated GEOS (Goddard Earth Observing System)-4 meteorological data. The interannual variations of $\mathrm{O}_{3}$ concentrations are quantified by values of mean absolute deviation (MAD) and absolute percent departure from the mean (APDM), based on the simulation of $\mathrm{O}_{3}$ for years 1986-2006 with changes in meteorological parameters but fixed anthropogenic emissions at year 2005 levels. The MAD values of JJA surface-layer $\mathrm{O}_{3}$ concentrations in China are in the range of 1.0-4.0 ppbv, with the largest values exceeding 2 ppbv found over northeastern China, coastal areas of southern China, and the Tibetan Plateau. The APDM values of JJA surface-layer $\mathrm{O}_{3}$ concentrations are 2-5\% over central eastern China, 1-3\% in northwestern China, and 5$10 \%$ over the Tibetan Plateau as well as the border and coastal areas of southern China. 
With fixed anthropogenic emissions, simulated JJA $\mathrm{O}_{3}$ concentrations averaged over China exhibit strong positive correlation (with a correlation coefficient of +0.75 ) with the East Asian summer monsoon index (EASMI) in the time period of 1986-2006, indicating that $\mathrm{JJA} \mathrm{O}_{3}$ concentrations are lower (or higher) in weaker (or stronger) EASM years. Relative to JJA surface-layer $\mathrm{O}_{3}$ concentrations in the strongest EASM years (1990, 1994, 1997, 2002, and 2006), $\mathrm{O}_{3}$ levels in the weakest EASM years (1988, 1989, 1996, 1998, and 2003) are lower over almost all of China with the national mean $\mathrm{O}_{3}$ concentration lower by $2.0 \mathrm{ppbv}$ (or $4 \%$ ).

Sensitivity studies are performed to identify the key processes through which the variations in EASM strength influence interannual variations of $\mathrm{JJA} \mathrm{O}_{3}$ in China. The difference in transboundary transport of $\mathrm{O}_{3}$ is found to be the most dominant factor that leads to lower $\mathrm{O}_{3}$ concentrations in the weakest EASM years than in the strongest EASM years. Relative to the strongest EASM years, the weakest EASM years have less inflow by $0.11 \mathrm{Tg}_{\text {season }}^{-1}$ at the west boundary, larger inflow fluxes of $\mathrm{O}_{3}$ by $4.2 \mathrm{Tg}$ season $^{-1}$ at the south boundary and by $5.5 \mathrm{Tg}$ season $^{-1}$ at the north boundary, and larger outflow by $12.9 \mathrm{Tg}$ season $^{-1}$ at the east boundary, as horizontal mass fluxes of $\mathrm{O}_{3}$ at the four lateral boundaries of the selected box $\left(85-120^{\circ} \mathrm{E}, 20-46^{\circ} \mathrm{N}\right.$, from the surface to $250 \mathrm{hPa}$ ) are calculated. As a result, the weakest EASM years have larger outflow of $\mathrm{O}_{3}$ than the strongest EASM years, which, together with the enhanced vertical convections in the weakest EASM years, explain about $80 \%$ of the differences in surface-layer $\mathrm{O}_{3}$ concentrations between the weakest and strongest EASM years.

We also perform a sensitivity simulation $\mathrm{O}_{3}$ EMIS to compare the impact of changing monsoon strength with that of changing anthropogenic emissions on JJA O 3 concentrations. Averaged over China, the change in JJA surface-layer $\mathrm{O}_{3}$ concentration owing to changes in emissions over years 1986-2006 is +5.3 ppbv, which is larger than the difference in JJA surface-layer $\mathrm{O}_{3}$ of $2.0 \mathrm{ppbv}$ between the selected weakest and strongest monsoon years. However, the difference in surface-layer $\mathrm{O}_{3}$ between the weak monsoon year 1998 and the strong monsoon year 1997 is -4.2 ppbv, indicating that the impacts of the EASM on $\mathrm{JJA} \mathrm{O}_{3}$ can be particularly strong for certain years. Note that while the largest increases in $\mathrm{O}_{3}$ by anthropogenic emissions are located over southeastern China, the largest impacts of EASM on $\mathrm{O}_{3}$ are found over central and western China.

Acknowledgements. This work was supported by the National Basic Research Program of China (973 Program, grant 2014CB441202), the Strategic Priority Research Program of the Chinese Academy of Sciences Strategic Priority Research Program grant no. XDA05100503, the National Natural Science Foundation of China under grant 41021004, as well as the China Meteorological Administration special funding in atmospheric science GYHY200906020.
Edited by: B. N. Duncan

\section{References}

An, Z., Porter, S. C., Kutzbach, J. E., Wu, X., Wang, S., Liu, X., Li, X., and Zhou, W.: Asynchronous Holocene optimum of the East Asian monsoon, Quaternary Sci. Rev., 19, 743-762, doi:10.1016/S0277-3791(99)00031-1, 2000.

Bey, I., Jacob, D. J., Yantosca, Logan, R. M., J. A., Field, B. D., Fiore, A. M., Li, Q., Liu, H. Y., Mickley, L. J., and Schultz, M. G.: Global modeling of tropospheric chemistry with assimi- lated meteorology: model description and evaluation, J. Geophys. Res., 106, 23073-23095, doi:10.1029/2001JD000807, 2001.

Chan, L. Y., Liu, H. Y., Lam, K. S., Wang, T., Oltmans, S. J., and Harris, J. M.: Analysis of the seasonal behavior of tropospheric ozone at Hong Kong, Atmos. Environ., 32, 159-168, doi:10.1016/S1352-2310(97)00320-8, 1998.

Chou, C. C. K., Liu, S. C., Lin, C. Y., Shiu, C. J., and Chang, K. H.: The trend of surface ozone in Taipei, Taiwan, and its causes: Implications for ozone control strategies, Atmos. Environ., 40, 3898-3908, doi:10.1016/j.atmosenv.2006.02.018, 2006.

Cheung, V. T. F. and Wang, T.: Observational study of ozone pollution at a rural site in the Yangtze Delta of China, Atmos. Environ., 35, 4947-4958, doi:10.1016/S1352-2310(01)00351-X, 2001.

Ding, A. and Wang, T.: Influence of stratosphere-to-troposphere exchange on the seasonal cycle of surface ozone at Mount Waliguan in western China, Geophys. Res. Lett., 33, L03803, doi:10.1029/2005GL024760, 2006.

Ding, A. J., Wang, T., Thouret, V., Cammas, J.-P., and Nédélec, P.: Tropospheric ozone climatology over Beijing: analysis of aircraft data from the MOZAIC program, Atmos. Chem. Phys., 8, 1-13, doi:10.5194/acp-8-1-2008, 2008.

Ding, Y. H. and Chan, J. C. L.: The East Asian summer monsoon: an overview, Meteorol. Atmos. Phys., 89, 117-142, doi:10.1007/s00703-005-0125-z, 2005.

Duan, J. C., Tan, J. H., Yang, L., Wu, S., and Hao, J. M.: Concentration, sources and ozone formation potential of volatile organic compounds (VOCs) during ozone episode in Beijing, Atmos. Res., 88, 25-35, doi:10.1016/J.Atmosres.2007.09.004, 2008.

Fiore, A. M., Horowitz, L. W., Purves, D. W., Levy, H., Evans, M. J., Wang, Y., Li, Q., and Yantosca, R. M.: Evaluating the contribution of changes in isoprene emissions to 25 surface ozone trends over the eastern United States, J. Geophys. Res., 110, D12303, doi:10.1029/2004JD005485, 2005.

Gao, J., Wang, T., Ding, A. J., and Liu, C. B.: Observational study of ozone and carbon monoxide at the summit of mount Tai $(1534 \mathrm{~m}$ a.s.l.) in central-eastern China, Atmos. Environ., 39, 4779-4791, doi:10.1016/j.atmosenv.2005.04.030, 2005.

Gao, Y. X.: Some Problems on East-Asia Monsoon, Science Press, Beijing, 49-63, 1962 (in Chinese).

Guenther, A., Karl, T., Harley, P., Wiedinmyer, C., Palmer, P. I., and Geron, C.: Estimates of global terrestrial isoprene emissions using MEGAN (Model of Emissions of Gases Aerosols from Nature), Atmos. Chem. Phys., 6, 3181-3210, doi:10.5194/acp6-3181-2006, 2006.

Han, Z. W., Ueda, H., and Matsuda, K.: Model study of the impact of biogenic emission on regional ozone and the effectiveness of emission reduction scenarios over eastern China, Tellus B, 57, 12-27, doi:10.1111/j.1600-0889.2005.00132.x, 2005. 
He, Y. J., Uno, I., Wang, Z. F., Pochanart, P., Li, J., and Akimoto, H.: Significant impact of the East Asia monsoon on ozone seasonal behavior in the boundary layer of Eastern China and the west Pacific region, Atmos. Chem. Phys., 8, 7543-7555, doi:10.5194/acp-8-7543-2008, 2008.

Huang, G.: An index measuring the interannual variation of the East Asian summer monsoon - The EAP index, Adv. Atmos. Sci., 21, 41-52, doi:10.1007/Bf02915679, 2004.

Intergovernmental Panel on Climate Change (IPCC), Climate change 2007: the physical science basis. Contribution of working group I to the fourth assessment report of the intergovernmental panel on climate change, edited by: Solomon, S., Qin, D., Manning, M., Chen, Z., Marquis, M., Averyt, K. B., Tignor, M., and Miller, H. L., Cambridge University Press, Cambridge, UK and New York, 1-996, 2007.

Jeong, J. I. and Park, R. J.: Effects of the meteorological variability on regional air quality in East Asia, Atmos. Environ., 69, 46-55, doi:10.1016/J.Atmosenv.2012.11.061, 2013.

Li, J. and Zeng, Q.: A unified monsoon index, Geophys. Res. Lett., 29, 115-1-115-4, doi:10.1029/2001GL013874, 2002.

Li, J., Wang, Z., Akimoto, H., Gao, C., Pochanart, P., and Wang, X.: Modeling study of ozone seasonal cycle in lower troposphere over east Asia, J. Geophys. Res., 112, D22S25, doi:10.1029/2006JD008209, 2007.

Lin, M., Holloway, T., Oki, T., Streets, D. G., and Richter, A.: Multiscale model analysis of boundary layer ozone over East Asia, Atmos. Chem. Phys., 9, 3277-3301, doi:10.5194/acp-9-3277-2009, 2009.

Lin, W., Xu, X., Zhang, X., and Tang, J.: Contributions of pollutants from North China Plain to surface ozone at the Shangdianzi GAW Station, Atmos. Chem. Phys., 8, 5889-5898, doi:10.5194/acp-8-5889-2008, 2008.

Liu, X., Chance, K., Sioris, C. E., Kurosu, T. P., Spurr, R. J. D., Martin, R. V., Fu, T. M., Logan, J. A., Jacob, D. J., Palmer, P. I., Newchurch, M. J., Megretskaia, I. A., and Chatfield, R. B.: First directly retrieved global distribution of tropospheric column ozone from GOME: comparison with the GEOS-CHEM model, J. Geophys. Res., 111, D02308, doi:10.1029/2005JD006564, 2006.

Lou, S. J., Liao, H., and Zhu, B.: Impacts of aerosols on surfacelayer ozone concentrations in China through heterogeneous reactions and changes in photolysis rates, Atmos. Environ., 85, 123138, doi:10.1016/j.atmosenv.2013.12.004, 2014.

McLinden, C. A., Olsen, S. C., Hannegan, B., Wild, O., Prather, M. J., and Sundet, J.: Stratospheric ozone in 3-D models: A simple chemistry and the cross-tropopause flux, J. Geophys. Res., 105, 14653-14665, doi:10.1029/2000JD900124, 2000.

Park, R. J., Jacob, D. J., Chin, M., and Martin, R. V.: Sources of carbonaceous aerosols over the United States and implications for natural visibility, J. Geophys. Res., 108, 4355, doi:10.1029/2002JD003190, 2003.

Park, R. J., Jacob, D. J., Field, B. D., Yantosca, R. M., and Chin, M.: Natural and transboundary pollution influences on sulfate-nitrate-ammonium aerosols in the United States: Implications for policy, J. Geophys. Res., 109, D15204, doi:10.1029/2003JD004473, 2004.

Piccot, S. D., Watson, J. J., and Jones, J. W.: A Global Inventory of Volatile Organic-Compound Emissions from
Anthropogenic Sources, J. Geophys. Res., 97, 9897-9912, doi:10.1029/92JD00682, 1992.

Pickering, K. E., Wang, Y. S., Tao, W. K., Price, C., and Muller, J. F.: Vertical distributions of lightning $\mathrm{NO}_{\mathrm{x}}$ for use in regional and global chemical transport models, J. Geophys. Res., 103, 3120331216, doi:10.1029/98JD02651, 1998.

Pochanart, P., Akimoto, H., Kinjo, Y., and Tanimoto, H.: Surface ozone at four remote island sites and the preliminary assessment of the exceedances of its critical level in Japan, Atmos. Environ., 36, 4235-4250, doi:10.1016/S1352-2310(02)00339-4, 2002.

Price, C. and Rind, D.: A Simple Lightning Parameterization for Calculating Global Lightning Distributions, J. Geophys. Res., 97, 9919-9933, doi:10.1029/92JD00719, 1992.

Seinfeld, J. H. and Pandis, S. N.: Atmospheric Chemistry and Physics, 2nd Edn., John Wiley \& Sons, Inc., Hoboken, New Jersey, 2006.

Shao, M., Tang, X. Y., Zhang, Y. H., and Li, W. J.: City clusters in China: air and surface water pollution, Front. Ecol. Environ., 4, 353-361, doi:10.1890/15409295(2006)004[0353:CCICAA]2.0.CO;2, 2006.

Shindell, D., Kuylenstierna, J. C. I., Vignati, E., van Dingenen, R., Amann, M., Klimont, Z., Anenberg, S. C., Muller, N., JanssensMaenhout, G., Raes, F., Schwartz, J., Faluvegi, G., Pozzoli, L., Kupiainen, K., Höglund-Isaksson, L., Emberson, L., Streets, D., Ramanathan, V., Hicks, K., Oanh, N. T. K., Milly, G., Williams, M., Demkine, V., and Fowler, D.: Simultaneously mitigating near-term climate change and improving human health and food security, Science, 335, 183-189, doi:10.1126/science.1210026, 2012.

Streets, D. G., Bond, T. C., Carmichael, G. R., Fernandes, S. D., Fu, Q., He, D., Klimont, Z., Nelson, S. M., Tsai, N. Y., Wang, M., Woo, J. H., and Yarber, K. F.: An inventory of gaseous and primary aerosol emissions in Asia in the year 2000, J. Geophys. Res., 108, 8809, doi:10.1029/2002JD003093, 2003.

Takami, A., Wang, W., Tang, D. G., and Hatakeyama, S.: Measurements of gas and aerosol for two weeks in northern China during the winter-spring period of 2000, 2001 and 2002, Atmos. Res., 82, 688-697, doi:10.1016/J.Atmosres.2006.02.023, 2006.

Tanimoto, H., Sawa, Y., Matsueda, H., Uno, I., Ohara, T., Yamaji, K., Kurokawa, J., and Yonemura, S.: Significant latitudinal gradient in the surface ozone spring maximum over East Asia, Geophys. Res. Lett., 32, L21805, doi:10.1029/2005GL023514, 2005.

Tang, J., Wen, Y. P., Xu, X. B., Zheng, X. D., Guo, S., and Zhao Y. C.: China Global Atmosphere Watch Baseline Observatory and its measurement program, in CAMS Annual Report 199495, 56-65, China Meteorol. Press, Beijing, 1995.

Tao, S. and Chen, L.: A Review of Recent Research on the East Asia Summer Monsoon in China, Monsoon Meteorology, Oxford University Press, Oxford, United Kingdom, 60-92, 1987.

Tu, J., Xia, Z. G., Wang, H. S., and Li, W. Q.: Temporal variations in surface ozone and its precursors and meteorological effects at an urban site in China, Atmos. Res., 85, 310-337, doi:10.1016/J.Atmosres.2007.02.003, 2007.

van der Werf, G. R., Randerson, J. T., Giglio, L., Collatz, G. J., Kasibhatla, P. S., and Arellano Jr., A. F.: Interannual variability in global biomass burning emissions from 1997 to 2004, Atmos. Chem. Phys., 6, 3423-3441, doi:10.5194/acp-6-3423-2006, 2006. 
van Donkelaar, A., Martin, R. V., Leaitch, W. R., Macdonald, A. M., Walker, T. W., Streets, D. G., Zhang, Q., Dunlea, E. J., Jimenez, J. L., Dibb, J. E., Huey, L. G., Weber, R., and Andreae, M. O.: Analysis of aircraft and satellite measurements from the Intercontinental Chemical Transport Experiment (INTEX-B) to quantify long-range transport of East Asian sulfur to Canada, Atmos. Chem. Phys., 8, 2999-3014, doi:10.5194/acp-8-2999-2008, 2008.

Wang, B. and Ding, Q.: Global monsoon: Dominant mode of annual variation in the tropics, Dynam. Atmos. Oceans, 44, 165-183, doi:10.1016/J.Dynatmoce.2007.05.002, 2008.

Wang, H. Q., Jacob, D. J., Le Sager, P., Streets, D. G., Park, R. J., Gilliland, A. B., and van Donkelaar, A.: Surface ozone background in the United States: Canadian and Mexican pollution influences, Atmos. Environ., 43, 1310-1319, doi:10.1016/j.atmosenv.2008.11.036, 2009.

Wang, H. X., Kiang, C. S., Tang, X. Y., Zhou, X. J., and Chameides, W. L.: Surface ozone: A likely threat to crops in Yangtze delta of China, Atmos. Environ., 39, 3843-3850, doi:10.1016/j.atmosenv.2005.02.057, 2005.

Wang, T., Wong, H. L. A., Tang, J., Ding, A., Wu, W. S., and Zhang, X. C.: On the origin of surface ozone and reactive nitrogen observed at a remote mountain site in the northeastern QinghaiTibetan Plateau, western China, J. Geophys. Res., 111, D08303, doi:10.1029/2005JD006527, 2006a.

Wang, T., Ding, A., Gao, J., and Wu, W. S.: Strong ozone production in urban plumes from Beijing, China, Geophys. Res. Lett., 33, L21806, doi:10.1029/2006GL027689, 2006b.

Wang, T., Wei, X. L., Ding, A. J., Poon, C. N., Lam, K. S., Li, Y. S., Chan, L. Y., and Anson, M.: Increasing surface ozone concentrations in the background atmosphere of Southern China, 19942007, Atmos. Chem. Phys., 9, 6217-6227, doi:10.5194/acp-96217-2009, 2009.

Wang, Y., McElroy, M. B., Munger, J. W., Hao, J., Ma, H., Nielsen, C. P., and Chen, Y.: Variations of $\mathrm{O}_{3}$ and $\mathrm{CO}$ in summertime at a rural site near Beijing, Atmos. Chem. Phys., 8, 6355-6363, doi:10.5194/acp-8-6355-2008, 2008.

Wang, Y., Zhang, Y., Hao, J., and Luo, M.: Seasonal and spatial variability of surface ozone over China: contributions from background and domestic pollution, Atmos. Chem. Phys., 11, 35113525, doi:10.5194/acp-11-3511-2011, 2011.

Wang, Z. F., Li, J., Wang, X. Q., Pochanart, P., and Akimoto, H.: Modeling of regional high ozone episode observed at two mountain sites (Mt. Tai and Huang) in East China, J. Atmos. Chem., 55, 253-272, doi:10.1007/S10874-006-9038-6, 2006.

Webster, P. J., Magana, V. O., Palmer, T. N., Shukla, J., Tomas, R. A., Yanai, M., and Yasunari, T.: Monsoons: Processes, predictability, and the prospects for prediction, J. Geophys. Res., 103, 14451-14510, doi:10.1029/97JC02719, 1998.

Wiedinmyer, C., Sakulyanontvittaya, T., and Guenther, A.: MEGAN FORTRAN Code V2.04 User Guide, available at: http: //acd.ucar.edu/ guenther/MEGAN/MEGAN.htm (last access: 31 January 2014), 2007.

Wild, O. and Akimoto, H.: Intercontinental transport of ozone and its precursors in a three-dimensional global CTM, J. Geophys. Res., 106, 27729-27744, doi:10.1029/2000JD000123, 2001.

Wild, O., Zhu, X., and Prather, M. J.: Fast-j: Accurate simulation of in- and below-cloud photolysis in tropospheric chemical models,
J. Atmos. Chem., 37, 245-282, doi:10.1023/A:1006415919030, 2000.

Wu, S. L., Mickley, L. J., Leibensperger, E. M., Jacob, D. J., Rind, D., and Streets, D. G.: Effects of 2000-2050 global change on ozone air quality in the United States, J. Geophys. Res., 113, D06302, doi:10.1029/2007JD008917, 2008.

Xu, X., Lin, W., Wang, T., Yan, P., Tang, J., Meng, Z., and Wang, Y.: Long-term trend of surface ozone at a regional background station in eastern China 1991-2006: enhanced variability, Atmos. Chem. Phys., 8, 2595-2607, doi:10.5194/acp-8-2595-2008, 2008.

Yamaji, K., Ohara, T., Uno, I., Tanimoto, H., Kurokawa, J., and Akimoto, H.: Analysis of the seasonal variation of ozone in the boundary layer in East Asia using the Community Multi-scale Air Quality model: What controls surface ozone levels over Japan?, Atmos. Environ., 40, 1856-1868, doi:10.1016/j.atmosenv.2005.10.067, 2006.

Yan, P., Li, X., Luo, C., Xu, X., Xiang, R., Ding, G., Tang, J., Wang, M., and Yu, X.: Observational Analysis of surface $\mathrm{O}_{3}, \mathrm{NO}_{\mathrm{x}}$, and $\mathrm{SO}_{2}$ in China, Appl. Meteor., 8, 53-61, 1997 (in Chinese).

Yan, P., Wang, M., Cheng, H., and Zhou, X. J.: Distributions and variations of surface ozone in Changshu, Yangtze Delta region, Acta Metall. Sin., 17, 205-217, 2003.

Yang, G., Fan, S., Tang, J., Jin, S., and Meng, Z.: Characteristic of surface ozone concentrations at Lin'an, Res. Environ. Sci., 21, 31-35, 2008 (in Chinese).

Ye, D. Z.: Some Characteristics of the Summer Circulation over the Qinghai-Xizang (Tibet) Plateau and Its Neighborhood, B. Am. Meteorol. Soc., 62, 14-19, doi:10.1175/15200477(1981)062<0014:Scotsc >2.0.Co;2, 1981.

Yienger, J. J. and Levy, H.: Empirical-Model of Global SoilBiogenic Nox Emissions, J. Geophys. Res., 100, 11447-11464, doi:10.1029/95JD00370, 1995.

Zhang, Y. H., Hu, M., Zhong, L. J., Wiedensohler, A., Liu, S. C., Andreae, M. O., Wang, W., and Fan, S. J.: Regional Integrated Experiments on Air Quality over Pearl River Delta 2004 (PRIDE-PRD2004): Overview, Atmos. Environ., 42, 6157-6173, doi:10.1016/J.Atmosenv.2008.03.025, 2008.

Zhao, C., Wang, Y., Yang, Q., Fu, R., Cunnold, D., and Choi, Y.: Impact of East Asian summer monsoon on the air quality over China: View from space, J. Geophys. Res., 115, D09301, doi:10.1029/2009JD012745, 2010.

Zhou, D., Ding, A., Mao, H., Fu, C., Wang, T., Chan, L. Y., Ding, K., Zhang, Y., Liu J., Lu, A., and Hao, N.: Impacts of the East Asian monsoon on lower tropospheric ozone over coastal South China, Environ. Res. Lett., 8, 044011, doi:10.1088/17489326/8/4/044011, 2013.

Zhou, L. T. and Huang, R. H.: Interdecadal variability of summer rainfall in Northwest China and its possible causes, Int. J. Climatol., 30, 549-557, doi:10.1002/joc.1923, 2010.

Zhu, B., Akimoto, H., Wang, Z., Sudo, K., Tang, J., and Uno, I.: Why does surface ozone peak in summertime at Waliguan?, Geophys. Res. Lett., 31, L17104, doi:10.1029/2004g1020609, 2004.

Zhu, J., Liao, H., and Li, J.: Increases in aerosol concentrations over eastern China due to the decadal-scale weakening of the East Asian summer monsoon, Geophys. Res. Lett., 39, L09809, doi:10.1029/2012GL051428, 2012. 